Meta

Journal des traducteurs

Translators' Journal

\title{
Towards a Typology of Literary Translation: Drama Translation Science
}

\section{Ortrun Zuber-Skerritt}

Volume 33, numéro 4, décembre 1988

Symposium AILA 1987, Sydney

URI : https://id.erudit.org/iderudit/004168ar

DOI : https://doi.org/10.7202/004168ar

Aller au sommaire du numéro

\section{Éditeur(s)}

Les Presses de l'Université de Montréal

ISSN

0026-0452 (imprimé)

1492-1421 (numérique)

Découvrir la revue

Citer cet article

Zuber-Skerritt, O. (1988). Towards a Typology of Literary Translation: Drama Translation Science. Meta, 33(4), 485-490. https://doi.org/10.7202/004168ar

\section{Résumé de l'article}

Based on the ideas of my two edited books The Languages of Theatre (Problems in the Translation and Transposition of Drama) and Page to Stage (Theatre as Translation), this paper attempts to arrive at a typology of translation which deals with both the translation of drama from one language and culture into another and with the various aspects of transposing the dramatic script on to the stage or, vice versa, the creation of drama through processes of theatre production. The focus is on those aspects of drama translation which are different from other forms of literary translation, e.g. on problems of semiotics (i.e. translating non-verbal signs in drama). The paper concludes with recommendations for future developments in drama translation research, including the production process, Le. the transposition from the written (translated) drama to the performed work of art, and the conceptualisation of the production process. 


\title{
TOWARDS A TYPOLOGY OF LITERARY TRANSLATION : DRAMA TRANSLATION SCIENCE
}

ORTRUN ZUBER-SKERRITT

Griffith University, Brisbane, Australia

\begin{abstract}
Based on the ideas of my two edited books The Languages of Theatre (Problems in the Translation and Transposition of Drama) and Page to Stage (Theatre as Translation), this paper attempts to arrive at a typology of translation which deals with both the translation of drama from one language and culture into another and with the various aspects of transposing the dramatic script on to the stage or, vice versa, the creation of drama through processes of theatre production. The focus is on those aspects of drama translation which are different from other forms of literary translation, e.g. on problems of semiotics (i.e. translating non-verbal signs in drama). The paper concludes with recommendations for future developments in drama translation research, including the production process, i.e. the transposition from the written (translated) drama to the performed work of art, and the conceptualisation of the production process.
\end{abstract}

Although the activity of translating is as old as the tower of Babel, translation science is a relatively new academic discipline. The domain of literary translation is one subdivision of translation science and drama translation is again a subsection of literary translation science.

This paper is based on some of the ideas published in my two volumes entitled The Languages of Theatre: Problems in the Translation and Transposition of Drama and Page to Stage : Theatre as Translation and suggests : (1) some classifications of drama translation and (2) some directions for future research which in my view would improve the understanding (a) of drama as a literary work, (b) of the translation process and (c) of the production process of drama as a performed art. Drama translation is defined as the translation of the dramatic text from one language and culture into another and as the transposition of the original, translated or adapted text onto the stage.

First, I wish to distinguish drama translation from other forms of literary translation (e.g. poetry, novels or short stories). A play written for a performance must be actable and speakable. Therefore, non-verbal and cultural aspects and staging problems have to be taken into consideration. As well as being a literary text, the translation of drama as a performing art is mainly dependent on the final production of the play on the stage and on the effectiveness of the play on the audience. A theatre performance is subject to changes according to audience reaction, acting performance, physical environment, and other factors. Whereas the published drama text remains irrevocable and permanent, each theatre performance based on this text is different and unique. Yet, drama translation science must be concerned both with the text as the basis for the stage production and the individual theatrical performances. One important tool of studying a performance and of overcoming the problem of its ephemerality - as compared with 
the stability of a dramatic text - is the use of film or of video technology, although the dimension of actor-audience interaction may still be missing.

Next, I wish to outline some of the main classifications of translation. Since Schleiermacher (1838), we distinguish between Verfremdung and Entfremdung. Verfremdung means distancing, estrangement or alienation of one's own language by understanding, following and adapting the language of the original. Entfremdung is dealienation of the foreign language by translating it into a language which the author would have used if he/she had lived in the time and place of the target language. There is no doubt that the latter is preferable, if not mandatory, in drama translation, for the audience must be familiar with the language in order to understand its meaning immediately. Similarly, Rose (1981) distinguishes between audience-adapted and textually autonomous translations, and Lefevere (1977) between reader-oriented and textoriented translations. Reiss (1976) classifies literary translations as being informative, expressive or operative, depending on whether they are instructing, affecting or persuading the reader. House (1977) differentiates between "overt" and "covert" translations, i.e. those which can be easily identified as translations and those texts which exist in their own right, no matter in which language. Other classifications are "literal" or "free", "scientific" or "artistic" translations. The former are housed in pure linguistics and based on theory, the latter are housed in applied linguistics and mainly founded on practice guided by "personal theory" (Polanyi 1962; Kelly 1963). Drama translation for obvious reasons of audience effectiveness should be in the latter category.

As to drama translation in particular, Gostand (1980) describes the various definitions, aspects and processes of the broad term "drama translation", firstly from :

- one language to another (difficulties of idiom, slang, tone, style, irony, wordplay or puns)

- one culture to another (customs, assumptions, attitudes)

one age/period to another (as above)

- one dramatic style to another (e.g. realistic or naturalistic to expressionistic or surrealistic)

one genre to another (tragedy to comedy or farce)

- one medium to another (stage play to radio, TV or film)

- straight play-script to musical/rock, opera/dance drama

- printed page to stage

- emotion/concept to happening

- verbal to non-verbal presentation

- one action group to another (professional-stage/film trained to amateur groups, students or children)

- one audience to another (drama for schools or the deaf)

Drama translation is also affected by interpretation on the part of the director, actors or by staging devices which influence the mood and atmosphere of the production, e.g. light/colour, pace, stage type, costume, mask/make-up, etc.

This leads me to mention the importance of non-verbal signs in drama translation. Zuber (1980b) gives an example of a taxonomy of non-verbal signs in Tennessee Williams' $\boldsymbol{A}$ Streetcar Named Desire, i.e. non-verbal signs which are significant for the meaning and message of the play, but which have caused problems in the German translation and theatre productions. The main classifications are briefly summarized in Table 1. 
TABLE 1 : Classifications of Symbolic Signs in Tennessee Williams' Work

1. VERBAL SYMBOLS

NON-VERBAL SYMBOLS

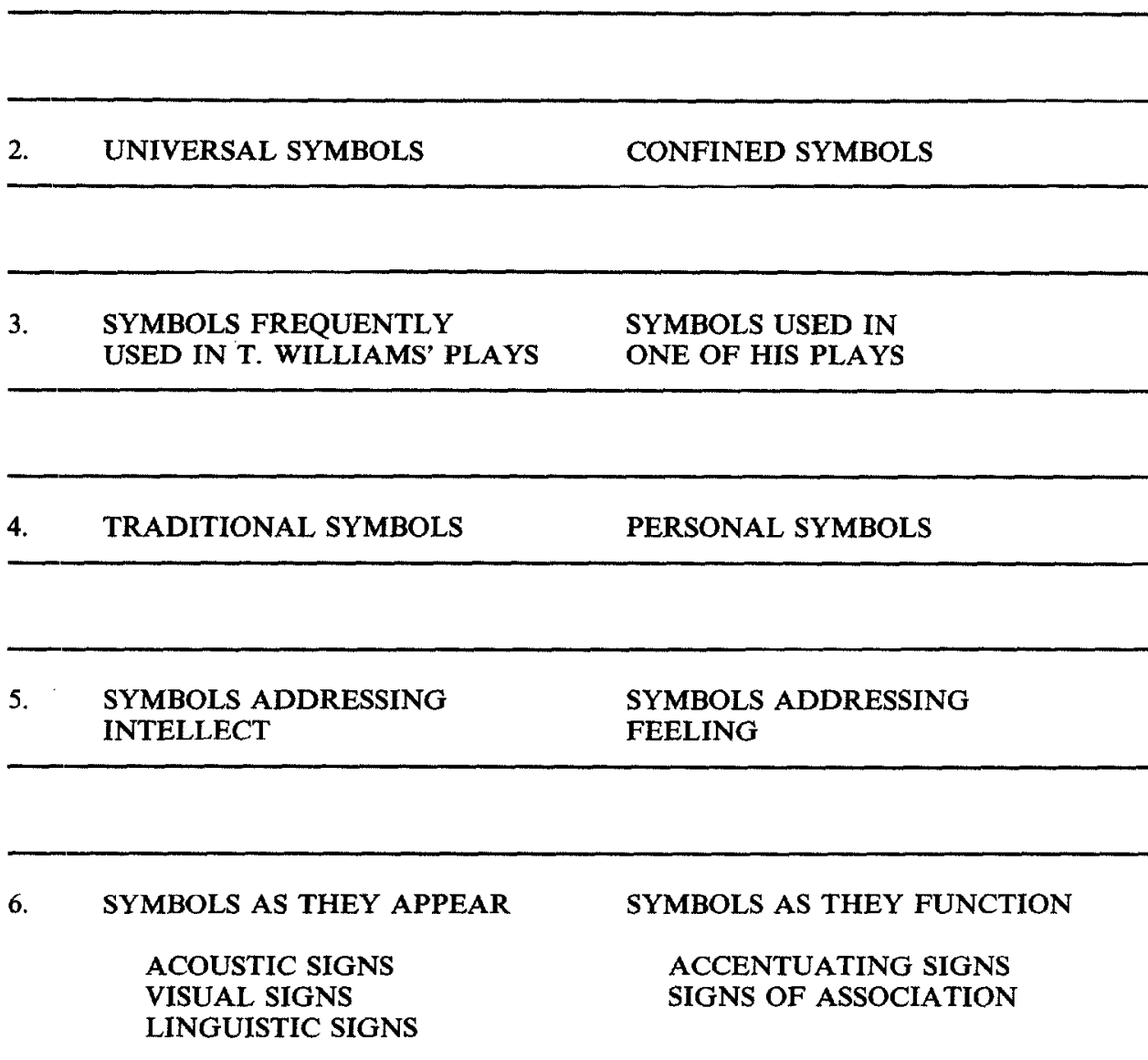

More specifically, the main symbolic signs in $A$ Streetcar Named Desire are represented in Figure 1. Zuber (1980b) discusses in detail how most of these signs are misrepresented in the German translation of the play, and why the American theatre reviews, on the one hand, and the German reviews, on the other, give the impression of two totally different plays.

Classifications, such as the above, may be interesting from a theoretical perspective; but when simultaneously aiming at the improvement of the practice of drama translation, a different kind of typology might be more useful. I mean a typology which focuses on the process of drama translation, i.e. (1) the process of translating the text into the target language and (2) the process of transposing the translated text on to the stage. 


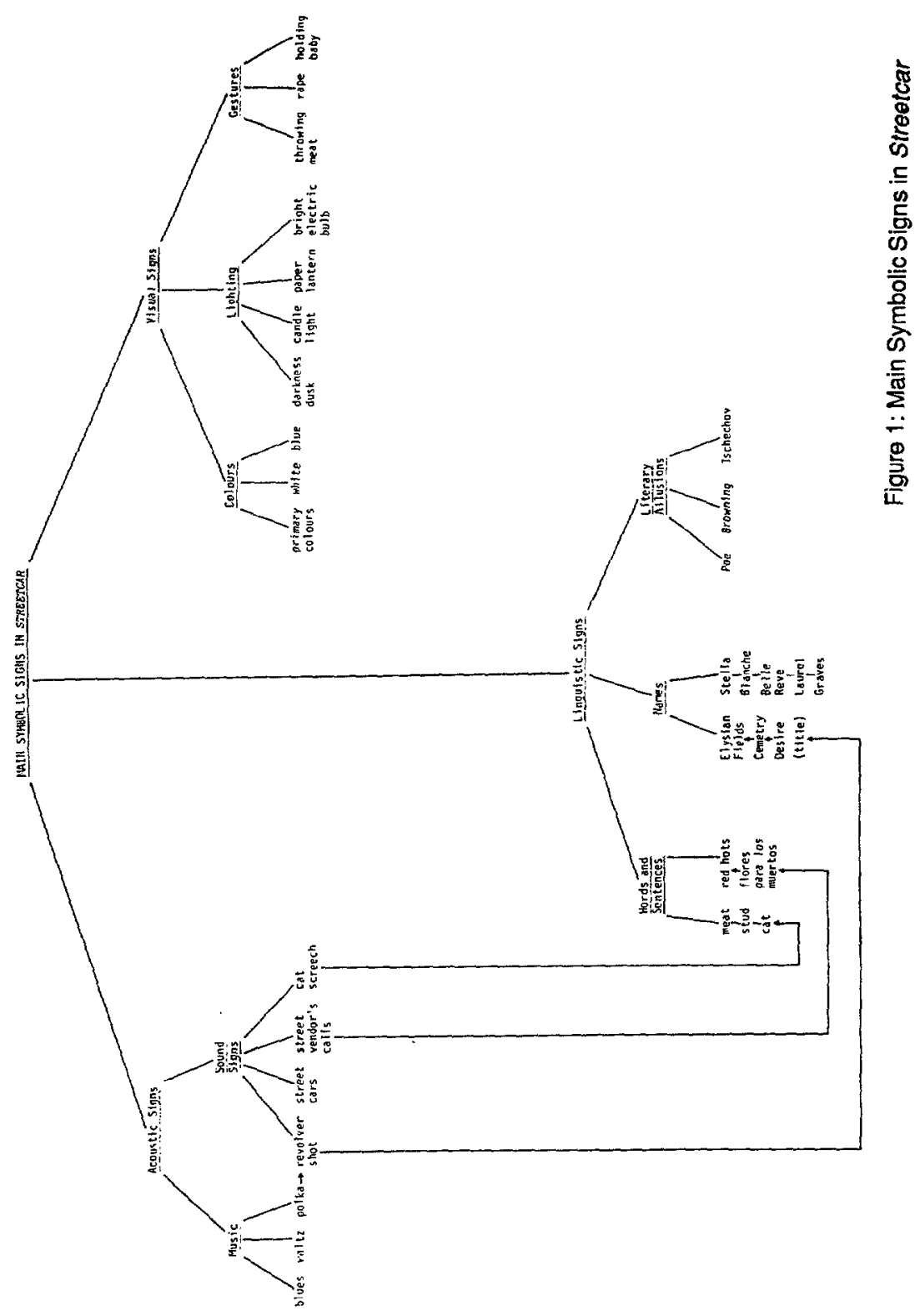


The first stage is covered by the first six steps (after Rose $1981: 1-7$ ) and the second stage by the next steps in the following scheme :

Step 1 : preliminary analysis of the text in order to decide whether it is worthy of translation;

Step 2 : exhaustive style and content analysis to establish what makes a literary text literary or what makes a scholarly text authoritative;

Step 3 : acclimation of the text by externalising the translation from the internal understanding of the source text ;

Step 4 : reformulation of the text and verbalisation in the target language, mostly proceeding from sentence to sentence and often modifying earlier analyses;

Step 5 : analysis of the translation which is revised (rarely fewer than three times and with time lapses between revisions) by the translator him/herself who as his/her own critic and editor measures his/her translation against the larger context of culture, audience needs or the intended text function;

Step 6 : review and comparison by another person being familiar with the original and able to judge whether comparable effects and functions are achieved and (if they are not) whether they are desirable ;

Step 7 : analysis of suitability for the stage to establish whether the text under consideration was written as a reading drama or for stage performances. For example, if it turns out to be a reading drama, it has to be established whether an acting edition exists ; and if there is no acting edition available, it has to be established whether the play is suitable for the stage and whether an acting edition should be produced;

Step 8: decision on what basis to use for the translation from page to stage. There are at least four possibilities for this transposition to be realised :

1. to follow a published acting edition;

2. to produce one's own acting edition;

3. to decide not to use a stage script at all, but to let the production evolve from trials and discussions in rehearsals, experiments, creative ideas and spontaneous interactions with the audience; or

4. to combine 3 with 1 or 2 .

This latter decision in step 8 will basically depend on one's views of drama as a literary genre, an artistic creation, or as the "authority" of a performance. It is advisable that the theatre group make their decision, whatever it may be, consciously and explicitly and that they communicate their ideas and intentions to the audience, e.g. in the theatre programme. This process of crystallising ideas will improve the theatre group's own understanding and professional confidence as well as the audience's understanding and, very importantly, the critics' fairer assessment of the performance according to the explicit criteria set by the director, producer and actors themselves, rather than by each individual critic remote from the production process.

Finally, I wish to point to five areas of research for future development in drama translation science. First, there is the study and schematisation of the production process itself. This process constitutes the transposition from the written (translated) drama to the performed work of art. A second area of research might be the influence which certain productions of translated plays have on the playwrights, critics and producers in the target country and on their work. Third, future research might usefully concentrate on translated drama as acted and produced, i.e. as a performing art. To date drama translation scientists have focused their research mainly on translated drama as the text basis for the stage production, rather than on the final performances. A fourth area of research might be the study of a performance of a play in the original language and culture in comparison with that of the same play in the target language and culture. 
Finally, future research might investigate the complex area of possibilities and determinants of interpretation of a performance. In the past this interpretation was mainly determined by the director/producer and carried out by the actors and designers under his/her supervision. In more recent times, with the permeation of democracy in the theatre, everyone involved in the performance may participate in the action and interpretation of the play, including the audience.

Video technology is a useful research tool, especially for the study of human interaction (Zuber-Skerritt 1984). Video recording and video analysis of a performance can be used for both the original and the translation of the play and for a comparison between the original and the translation, or a comparison with other performances of this play in the target language.

The research results may be useful to students and teachers of drama, to translators, producers, actors, libraries (archives) and to other researchers in drama translation science.

To conclude, a typology of drama translation science includes considerations of classifying literary translation in general as well as particular aspects of translation from Page to Stage, i.e. the process of transposing the translated text into a speakable and actable performance, including the translation of non-verbal signs.

\section{REFERENCES}

GOSTAND, R. (1980) : "Verbal and Non-Verbal Communication : Drama as Translation", in O. Zuber (ed.) :

The Languages of Theatre: Problems in the Translation and Transposition of Drama, Oxford, Pergamon Press, pp. 1-9.

HOUSE, J. (1977) : A Model for Translation Quality Assessment, Tübingen, Verlag Gunther Narr.

KELLY, G.A. (1963) : A Theory of Personality, New York, Norton.

LEFEVERE, A. (1977) : Translating Literature : The German Tradition, Assen (Holland), Van Gorcum.

POLANYI, M. (1962) : Personal Knowledge : Towards a Post-Critical Philosophy, London, Routledge and Kegan Paul

REISS, K. (1976) : Texttyp und Übersetzungsmethode, Kronberg/Ts, Scriptor Verlag

ROSE, M.G. (1981) : Translation Spectrum, Albany, State University of New York Press.

SCHLEIERMACHER, F. (1838) : "Über die verschiedenen Methoden des Übersetzens", in Sämtliche Werke, 2, Berlin, pp. 207-245.

ZUBER, O. (1980a): The Languages of Theatre: Problems in the Translation and Transposition of Drama, Oxford, Pergamon Press.

ZUBER, O. (1980b) : "The Translation of Non-Verbal Signs in Drama", in M.G. Rose (ed.) : Translation : Agent of Communication, Hamilton (NZ), Outrigger Publishers, pp. 61-74

ZUBER-SKERRITT, O. (1984) : Page to Stage: Theatre as Translation, Amsterdam, Rodopi

ZUBER-SKERRITT, O. (1984) : Video in Higher Education, London, Kogan Page. 